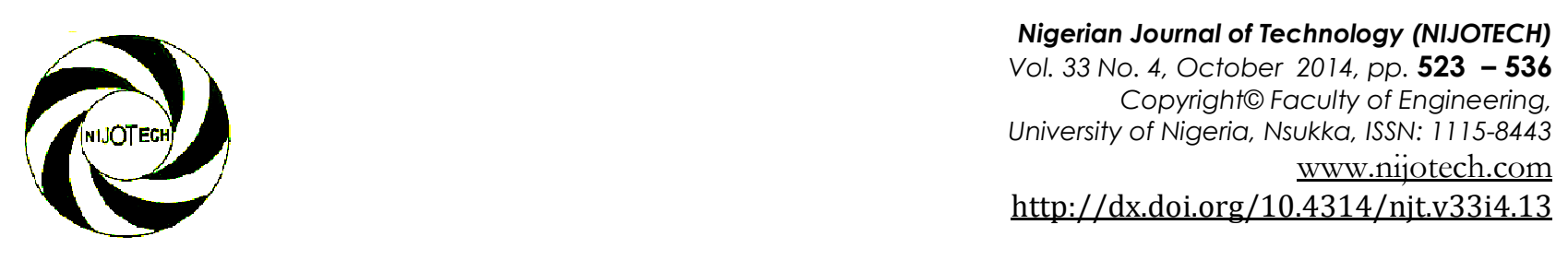

\title{
EXERGETIC MODELLING OF OIL-FIRED STEAM BOILERS
}

\author{
I. O. Ohijeagbon ${ }^{1,}{ }^{*}$, M. A. Waheed ${ }^{2}$, S. 0. Jekayinfa ${ }^{3}$ and 0. A. Lasode ${ }^{4}$ \\ 1,4 MECHANICAL ENGINEERING DEPARTMENT, UNIVERSITY OF ILORIN, ILORIN, NIGERIA \\ 2MEChANiCAL ENGINEERING DEPARTMENT, UNIVERSITY OF Agriculture, ABEOKUTA, NIGERIA \\ ${ }^{3}$ AgRicultural EngINEERING DEPARTMENT, LAdOKE AKINTOLA UnIVERSITY OF TECHNOLOGY, OGBOMOSO, NIGERIA \\ E-mail addresses: 1 idehaiohi@yahoo.com,2akindoye@yahoo.com, ${ }^{3}$ jekaysol@yahoo.com, 4 oalasode@yahoo.com
}

\begin{abstract}
The performance variables and potential for energy savings in oil-fired industrial steam boilers were studied. Operational parameters of steam boilers using low pour fuel oil (LPFO) and diesel were used to determine thermodynamic properties of material streams and exergetic parameters. Analysis of thermodynamic properties on exergetic performance of boilers was conducted. Exergetic models developed are also presented. The ratio of the energy to exergy efficiencies of the heat exchanging unit and of the entire steam boiler was determined as 1.4 and 1.8614 respectively. The average overall boiler exergy destruction decreased by $14.62 \%$, as the evaporation ratio increased from 10 to 14 though heat loss in boiler was found to increase with increases in evaporation ratio. Developed models in this study could be employed to analyse and estimate exergetic performance indices of oilfired steam boilers in order to enhance their efficiencies and reduce energy wastage.
\end{abstract}

Keywords: exergetic efficiency; steam boilers; oil-fired; operational parameters

\begin{tabular}{|c|c|}
\hline \multicolumn{2}{|r|}{ LIST OF SYMBOLS } \\
\hline $\begin{array}{l}A A F \\
A F R_{s t}\end{array}$ & $\begin{array}{l}\text { actual and stoichiometric air-fuel ratio ( } \mathrm{kg} \text { of } \\
\text { air } / \mathrm{kg} \text { of fuel) }\end{array}$ \\
\hline$e_{x \mathrm{CO}_{2}}^{c h}$ & $\begin{array}{l}\text { molar chemical exergy of carbon dioxide } \\
\left(\mathrm{CO}_{2}\right), \mathrm{kJ} / \mathrm{kmol}\end{array}$ \\
\hline$e_{x \text { fuel }}^{\text {ch }}$ & molar chemical exergy of fuel, $\mathrm{kJ} / \mathrm{kmol}$ \\
\hline$e_{x_{\mathrm{H}_{2} \mathrm{O}} \mathrm{O}}^{c h}$ & $\begin{array}{l}\text { molar chemical exergy of water vapour } \\
\left(\mathrm{H}_{2} \mathrm{O}\right), \mathrm{kJ} / \mathrm{kmol}\end{array}$ \\
\hline$e_{x O_{2}}^{c h}$ & $\begin{array}{l}\text { molar chemical exergy of oxygen }\left(\mathrm{O}_{2}\right) \text {, } \\
\mathrm{kJ} / \mathrm{kmol}\end{array}$ \\
\hline$E_{\text {in }}$ & the energy input in the combustion unit, $\mathrm{kJ} / \mathrm{s}$ \\
\hline $\bar{g}$ & standard Gibbs function, $\mathrm{kJ} / \mathrm{kmol}$ \\
\hline $\bar{g}_{\mathrm{CO}_{2}}$ & $\begin{array}{l}\text { standard Gibbs function of carbon dioxide } \\
\left(\mathrm{CO}_{2}\right), \mathrm{kJ} / \mathrm{kmol}\end{array}$ \\
\hline $\bar{g}_{H_{2}} \mathrm{O}(v)$ & $\begin{array}{l}\text { standard Gibbs function of water vapour } \\
\left(\mathrm{H}_{2} \mathrm{O}\right), \mathrm{kJ} / \mathrm{kmol}\end{array}$ \\
\hline $\bar{g}_{O_{2}}$ & $\begin{array}{l}\text { standard Gibbs function of oxygen }\left(\mathrm{O}_{2}\right) \text {, } \\
\mathrm{kJ} / \mathrm{kmol}\end{array}$ \\
\hline$H$ & specific enthalpy, $\mathrm{kJ} / \mathrm{kg}$ \\
\hline$h_{0}$ & reference state enthalpy, $\mathrm{kJ} / \mathrm{kg}$ \\
\hline$H H V$ & high or gross heating value of fuel, $\mathrm{kJ} / \mathrm{kg}$ \\
\hline$\dot{I}$ & exergy destruction rate, $\mathrm{kJ} / \mathrm{s}$ \\
\hline$L H V$ & low or net heating value of fuel, $\mathrm{kJ} / \mathrm{kg}$ \\
\hline LPFO & low pour fuel oil \\
\hline$\dot{m}_{e}$ & exit mass flow rate, $\mathrm{kg} / \mathrm{s}$ \\
\hline
\end{tabular}

\begin{tabular}{|c|c|}
\hline$\dot{m}_{i}$ & inlet mass flow rate, $\mathrm{kg} / \mathrm{s}$ \\
\hline $\begin{array}{c}M \\
P\end{array}$ & $\begin{array}{l}\text { molar mass of chemical substance, } \mathrm{kg} / \mathrm{kmol} \\
\text { pressure, } \mathrm{N} / \mathrm{m}^{2}\end{array}$ \\
\hline$\dot{Q}$ & heat transfer rate to the system, $\mathrm{kJ} / \mathrm{s}$ \\
\hline$Q_{H(\text { loss })}$ & hHeat loss in heat exchanging unit, $\mathrm{kJ} / \mathrm{s}$ \\
\hline $\bar{R}$ & $\begin{array}{l}\text { molar or universal gas constant, } \\
\mathrm{kJ} / \mathrm{kmol} K\end{array}$ \\
\hline$S$ & specific entropy, $\mathrm{kJ} / \mathrm{kg} \mathrm{K}$ \\
\hline$s_{0}$ & reference state entropy, $\mathrm{kJ} / \mathrm{kg} \mathrm{K}$ \\
\hline$T$ & temperature, ${ }^{o} C, K$ \\
\hline$T_{0}$ & reference state temperature, ${ }^{\circ} C, K$ \\
\hline & CHEMICAL SYMBOLS \\
\hline$A r$ & argon \\
\hline$C$ & carbon \\
\hline $\mathrm{CO}_{2}$ & carbon dioxide \\
\hline$C_{x} H_{y}$ & hydrocarbon (fossil fuel) molecules \\
\hline$H$ & hydrogen \\
\hline $\mathrm{H}_{2} \mathrm{O}$ & water \\
\hline$N_{2}$ & nitrogen \\
\hline $\mathrm{O}, \mathrm{O}_{2}$ & oxygen \\
\hline
\end{tabular}

\section{SUBSCRIPTS}

0 reference state

Oa reference state of air

$A \quad$ air

Atm atmospheric

* Corresponding author, Tel: +234-703-009-2411 
$B \quad$ boiler

C combustion unit

$F \quad$ Fuel

$G \quad$ exhaust flue gas

$H \quad$ heat exchanging unit

in in

out out

$P \quad$ hot products

$S \quad$ Steam

W feed water

\begin{tabular}{ll} 
& \multicolumn{1}{c}{ SUPERSCRIPTS } \\
ch & Chemical \\
ph & Physical
\end{tabular}

\begin{tabular}{|c|c|}
\hline & GREEK LET \\
\hline$\Delta \bar{g}$ & the change in the standard Gibbs function, \\
\hline $\mathcal{E}$ & $\begin{array}{l}\mathrm{kJ} / \mathrm{kmol} \\
\text { snecific exerov }(\mathrm{kJ} / \mathrm{k} \sigma)\end{array}$ \\
\hline & exit specific flow exergy of material streams, \\
\hline$\varepsilon_{e}$ & $\mathrm{~kJ} / \mathrm{s}$ \\
\hline$\varepsilon^{c h}$ & specific chemical flow exergy, $\mathrm{kJ} / \mathrm{kg}$ \\
\hline$\varepsilon^{p h}$ & specific physical flow exergy, $\mathrm{kJ} / \mathrm{kg}$ \\
\hline$\eta$ & energy efficiency (\%) \\
\hline$\psi$ & exergy efficiency (\%) \\
\hline
\end{tabular}

\section{INTRODUCTION}

Steam boilers are widely applied for process heating, sterilization, drying, material conditioning and saponification in bottling, pharmaceutical, tobacco and soap industries; and also for production of mechanical and electrical energy. Energy is consumed, conserved and dissipated in steam boilers when engaged in producing steam for different end uses by combustion of fuel.

For any given environment, energy which may be converted into other forms is called useful energy or exergy. And energy which cannot be converted into other energy forms is called useless energy or anergy [1]. When all processes of the system and the environment are reversible, exergy is fully conserved. Exergy is destroyed whenever an irreversible process takes place. Exergy destruction is a measure of the thermodynamic imperfections determined when an exergy analysis is performed on a plant such as an entire power station, a chemical processing plant or a refrigeration plant, and this refers to wasted work or wasted potential for the production of work [2].

Exergy is a useful concept for determining improvement, since it is a connection between the physical and engineering world and the surrounding environment, and expresses the true efficiency of engineering systems. Exergy analysis has been applied in the design of engineering systems as well as sectoral energy and exergy consumption [3]. There has been an increasing interest in applying energy and exergy analysis modelling techniques for energyutilization assessments in order to obtain energy savings in recent years [4]. Exergy analysis is a methodology for the assessment of the performance of devices and processes, and involves analysing the exergy at different points in a series of energyconversion steps [6]. Consequently, efficiencies can be evaluated, and the process steps having the largest losses (i.e., the greatest margin for improvement) can be identified. Exergy analysis has been found to be a highly versatile method by many scientists, engineers, managers, decision and policy makers. Exergy analysis has been employed in many spectra of socioeconomic and industrial infrastructure such as, analysing and evaluating the energy utilization efficiency of countries, steam and thermal power plants, combustion and energy conversion processes, iron smelting processes, etc. It has been established to be a very useful tool for determining operational improvements and energy savings of industrial processes and products [7-10].

Suresh et. al [11] conducted a study to predict the possible improvement in efficiency obtained with thermal power plants. The study dealt with the comparison of energy and exergy analysis of thermal power plants based on advanced steam parameters in Indian climatic conditions. The study involved coalbased thermal power plants using subcritical, supercritical, and ultrasupercritical steam conditions. The design configurations of 500 MWe unit size were considered. The study encompassed the effect of condenser pressure on plant and exergy efficiency. The effect of high grade coal on performance parameters as compared to typical Indian low grade coal was also studied. The major exergy loss took place in coal combustion followed by the steam generator. Due to condenser pressure limitation, the maximum possible plant efficiency was found to be about $41 \%$ for supercritical steam power plant and $44.4 \%$ for the ultrasupercritical steam power plant. It was therefore concluded that installing coal-based thermal power plants based on advanced steam parameters in India will be a prospective option aiding energy self-sufficiency.

The persistent increase in energy demand for economic development and the need for the preservation of the environment are indications that energy systems ought to become more efficient [12]. 
Attempts have been made by other researchers to combine mathematical or economical methods and advanced thermodynamic processes to investigate and improve plant systems, and also to study and minimize the effects of irreversibility. Ataei and Yoo [13] performed the simulation of a $325 \mathrm{MW}$ steam power plant in which the operational parameters of the Rankine cycle were optimized using the exergy concept combined with a pinch-based approach in the study of combined pinch and exergy analysis for energy efficiency optimization in a steam power plant. Srinivas et. al [14] conducted a thermodynamic analysis of the effect of ' $n$ ' feedwater heaters on performance of a steam power cycle with a generalized mathematical formulation. They carried out performance calculations formulated separately to a single feedwater heater and extended to ' $n$ ' feedwater heaters for parametric study. The work of Srinivas et. al [14] examined the improvements in efficiency with increases in boiler pressure, turbine inlet temperature and furnace temperature, and they were able to determine the maximum gain in the efficiency of the cycle. Gutierrez and Mendez [15] developed a theoretical analysis to minimize the entropy generation of a thermo-electric cooler. They applied an analysis of first and second law of Thermodynamics to thermo-electric cooler, and considered the entropy generation equation as the objective function and the first law as a restriction, in accordance with the variational calculus theory. Their numerical estimations indicated that minimum entropy generation and the better performance coefficients (COPs) were achieved with the largest figure of merit, which represented a relationship between the Peltier effect (cooling) and the Joule effect (heating).

It is imperative to adopt reliable methods to assess the performance of industrial facilities, such as steam boiler, for sustainable use. The performance of steam boilers could be assessed based on operational and output parameters which are of primary interest to a researcher or other stakeholders. In a study of an oilfired boiler system, Orosun and Adamu [16] modelled steam boiler as a multivariable plant with two inputs, namely, feed water rate and oil-fired flow rate; and two outputs, which were steam temperature and pressure. The authors modelled the plant parameters using artificial neural network. Their result showed a correlation of 0.97 in the simulated and actual outputs for temperature and pressure respectively. They however did not consider the exergetic analysis of the steam boiler. Igboanugo et. al [17] had also studied the performance characteristics of a boiler unit using failure mode effect and fault tree analyses, the energy source for the boiler was low grade fuel from palm oil bunch and fibre. The study revealed that in a single shift operating mode of eight hours, a time of 72 minutes was saved arising from the effectiveness of the plant overhaul carried out. They obtained an energy efficiency of $54.2 \%$ at boiler operating pressure of $700 \mathrm{kN} / \mathrm{m}^{2}$. The effect of irreversibility, exergy destruction and efficiency were not analysed in the study.

This study is aimed at investigating the exergetic performances, developing of exergetic models and potential of energy savings through investigation of the effects of various thermodynamic and operational variables in oil-fired industrial steam boilers.

\section{METHOD}

\subsection{Material streams in steam boiler}

The basic influx of material streams in a boiler as exemplified by Figure 1 which is an exploded view of the model of Saidur et. al [18], takes place in the combustion unit and heat exchanging unit. The intake air (from ambient air supply) mixes with the combustion fuel, usually hydrocarbon in a chemical oxidation process to release heat energy in the furnace. Combustion of LPFO and diesel fuels was used in this study. The hot product of combustion exiting the furnace enters the heat exchanging unit in which the supplied heat energy is utilised to transform the feed water entering into the heat exchanging unit into saturated steam. The saturated steam may further be heated in the superheater by hot flue gases from the furnace to obtain superheated steam. The flue gases and heat loss exit the boiler to complete the material and energy flow process in the boiler.

\subsection{Operational parameters}

The general specifications of the boiler investigated are presented in Table 1. This shows that the boiler is a fire tube type and horizontal in orientation. It is internally fired, forced circulation, low pressure and stationary. It is also a multi-tube and operates on either LPFO or diesel fuels. The operating steam temperature, maximum steam pressure and operating steam pressure are $180{ }^{\circ} \mathrm{C}, 1600 \mathrm{kN} / \mathrm{m}^{2}$ and $750 \mathrm{kN} / \mathrm{m}^{2}$ respectively. The steam generated from boiler is for the purpose of boiling, steam regeneration of carbon filter, and sterilization. 


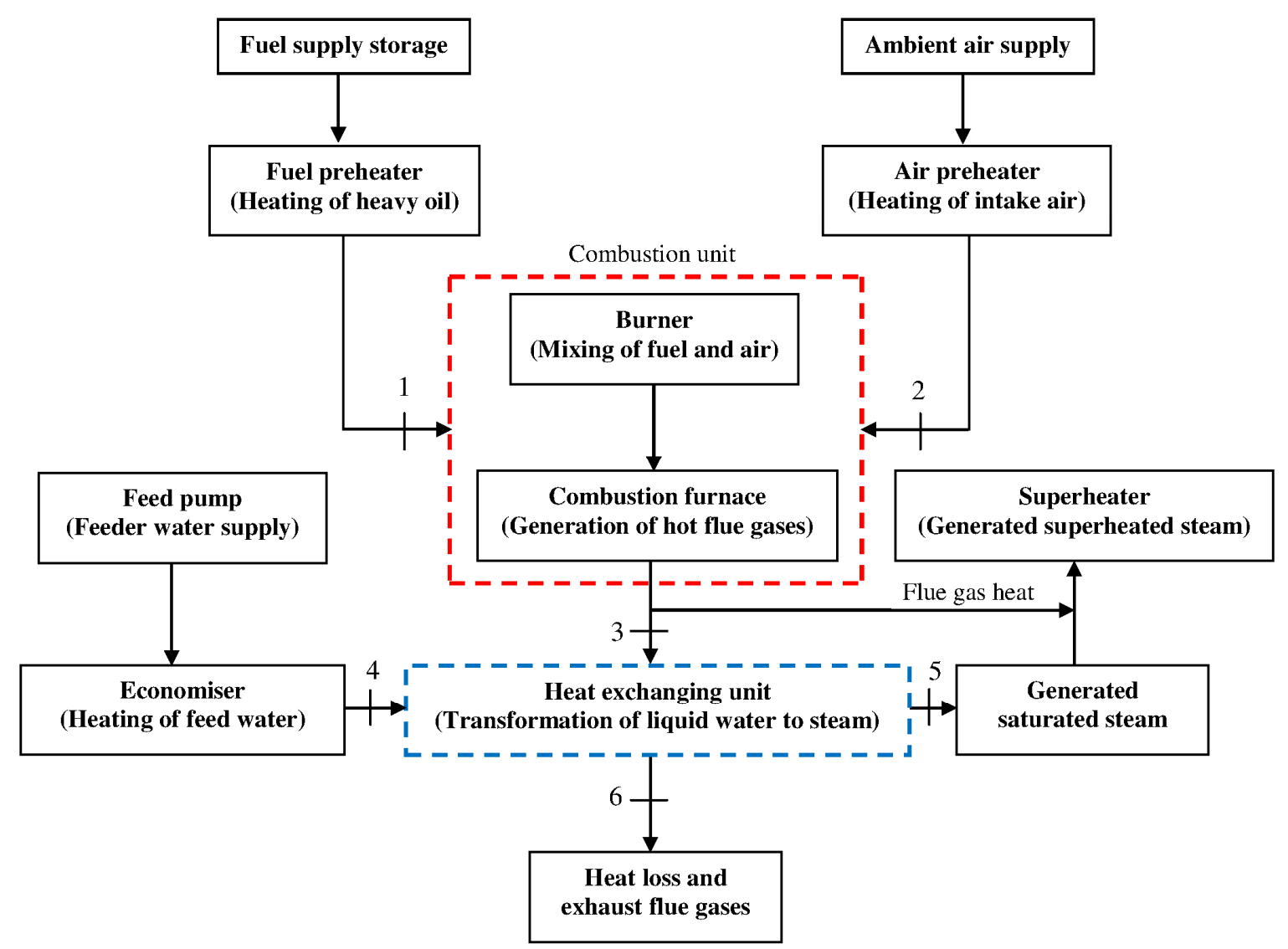

Figure 1: Material streams flow diagram in a steam boiler

The operational parameters used in this study are enumerated in Table 2 for both LPFO and diesel operation. Similar values had been adopted for the air temperature, steam pressure, mass flow rate of fuel, evaporation ratio, and excess air. The fuels have their peculiar specific heat capacities, stoichiometric and actual fuel ratios respectively as presented in Table 2. The specific heat capacity, stoichiometric and actual fuel ratios of LPFO operated boiler are $1.866 \mathrm{~kJ} / \mathrm{kgK}, 13.428$ and $16.114 \mathrm{~kg}$ of air $/ \mathrm{kg}$ of fuel, while that of diesel operated boiler are 1.9612 $\mathrm{kJ} / \mathrm{kgK}, 14.128$ and $17.00 \mathrm{~kg}$ of air $/ \mathrm{kg}$ of fuel respectively. The distinction in the peculiar thermodynamic properties is expected to influence the nature of exergetic performances of LPFO and diesel operated boilers.

Table 1: Specification of industrial steam boiler investigated

\begin{tabular}{ll}
\hline Details & Specification \\
\hline 1. Orientation & Horizontal \\
2. Type of tube & Fire tube \\
3. Type of firing & Internally fired \\
4. Type of circulation & Forced \\
5. Type of pressure & Low \\
6. Stationary or portable & Stationary \\
7. Single or multi-tube & Multi-tube \\
8. Type of fuel used & LPFO and Diesel \\
\hline
\end{tabular}

\begin{tabular}{ll}
\hline Details & Specification \\
\hline $\begin{array}{l}\text { 9. Operating steam temperature } \\
\left({ }^{0} \mathrm{C}\right)\end{array}$ & 180 \\
$\begin{array}{l}\text { 10. Maximum steam pressure } \\
\left(\mathrm{kN} / \mathrm{m}^{2}\right)\end{array}$ & 1600 \\
$\begin{array}{l}\text { 11. Operating steam pressure } \\
\left(\mathrm{kN} / \mathrm{m}^{2}\right)\end{array}$ & 750 \\
& $\begin{array}{l}\text { Boiling, steam } \\
\text { regeneration of } \\
\text { carbon filter, } \\
\text { sterilization }\end{array}$ \\
\hline
\end{tabular}

Table 2: Parameters for the LPFO and diesel operation of boiler [19-20]

\begin{tabular}{|c|c|c|}
\hline Parameter & $\begin{array}{c}\text { LPFO } \\
\text { operated }\end{array}$ & $\begin{array}{c}\text { Diesel } \\
\text { operated }\end{array}$ \\
\hline Air temperature $\left({ }^{0} \mathrm{C}\right)$ & 77.00 & 77.00 \\
\hline Steam pressure $\left(\mathrm{kN} / \mathrm{m}^{2}\right)$ & 800.00 & 800.00 \\
\hline $\begin{array}{l}\text { Rate of fuel consumption } \\
(\mathrm{kg} / \mathrm{s})\end{array}$ & 0.18 & 0.18 \\
\hline Evaporation ratio, $\mathrm{E}_{\mathrm{r}}$ & 12 & 12 \\
\hline $\begin{array}{l}\text { Specific heat capacity, } c_{p} \\
(\mathrm{~kJ} / \mathrm{kgK})\end{array}$ & 1.866 & 1.9612 \\
\hline $\begin{array}{l}\text { Stoichiometric air-fuel } \\
\text { ratio, } \mathrm{AFR}_{\text {st }} \\
\text { (kg of air } / \mathrm{kg} \text { of fuel) }\end{array}$ & 13.428 & 14.128 \\
\hline $\begin{array}{l}\text { Actual air-fuel ratio, AAF } \\
\text { (kg of air/kg of fuel) }\end{array}$ & 16.114 & 17.00 \\
\hline Excess air, EA (\%) & 20 & 20 \\
\hline
\end{tabular}




\subsection{Mass balance of material streams}

Conservation of mass and energy balance was applied to the boiler system in addition to the evaporation ratio and air fuel ratio and were used to determine mass flow rates of substances of all material streams in the boiler, such as; air, $\dot{m}_{a}$, fuel, $\dot{m}_{f}$, hot products, $\dot{m}_{p}$, feed water, $\dot{m}_{w}$, steam, $\dot{m}_{s}$ and flue gas, $\dot{m}_{g}$ [19].

Hence,

$$
\begin{aligned}
& \dot{m}_{a}+\dot{m}_{f}=\dot{m}_{p} \\
& \dot{m}_{p}=\dot{m}_{g} \\
& \dot{m}_{w}=\dot{m}_{s}
\end{aligned}
$$

The evaporation ratio of a boiler can be expressed by [19-21];

$$
E_{r}=\frac{\dot{m}_{s}}{\dot{m}_{f}}
$$

\subsection{Energy and exergy analysis of boiler}

The physical and chemical exergy associated with material streams for a flow process makes up the total flow exergy transfer which is the theoretically obtainable work when the substance is brought into total equilibrium with the local environment [22-25]. Ertesvag [26] presents the total flow exergy transfer by equation (5), while the specific physical flow exergy is given by equation (6).

$$
\begin{aligned}
& \varepsilon=\varepsilon^{p h}+\varepsilon^{c h} \\
& \varepsilon^{p h}=h-h_{0}-T_{0}\left(s-s_{0}\right)
\end{aligned}
$$

The method of determining the chemical exergy of fuels is similar to that used in methodology for the physical and chemical exergetic analysis of steam boilers [19] and cumulative exergetic assessment of LPFO utilized steam boilers [20], and are as follows [25, 27-28];

Table 3: Chemical exergies, standard Gibbs functions of formation and mole fractions of components of atmospheric air at reference conditions of $25^{\circ} \mathrm{C}$ and $1 \mathrm{~atm}$ [19, 26-27]

\begin{tabular}{lccc}
\hline Components & $\begin{array}{c}\text { Chemical exergies } \\
\text { (kJ/kmol) } \\
(70 \% \text { relative humidity) }\end{array}$ & $\begin{array}{c}\text { Standard Gibbs } \\
\text { function, } \bar{g} \\
(\mathrm{~kJ} / \mathrm{kmol})\end{array}$ & $\begin{array}{c}\text { Mole fraction composition } \\
\text { of a reference environment } \\
\text { model }\end{array}$ \\
\hline Nitrogen, $\mathrm{N}_{2}$ & 668.10 & 0 & 0.7565 \\
Oxygen, $\mathrm{O}_{2}$ & $3,930.50$ & 0 & 0.2035 \\
$\mathrm{Carbon}$ dioxide, $\mathrm{CO}_{2}$ & $19,610.00$ & $-394,390$ & 0.0003 \\
$\mathrm{Argon}, \mathrm{Ar}$ & $11,640.00$ & 0 & 0.0091 \\
Water, $\mathrm{H}_{2} \mathrm{O}$ (g) & $9,474.00$ & $-228,590$ & 0.0303 \\
Water, $\mathrm{H}_{2} \mathrm{O}$ (liq) & 884.20 & $-237,150$ & - \\
$\mathrm{Hydrogen}, \mathrm{H}_{2}$ & $236,098.00$ & 0 & 0.0001 \\
Carbon monoxide, $\mathrm{CO}$ & $274,870.00$ & $-137,160$ & - \\
\hline
\end{tabular}




\begin{tabular}{lll}
\hline Specifications & \multicolumn{1}{c}{$\begin{array}{c}\text { LPFO } \\
\text { (No. 6 Oil) }\end{array}$} & \multicolumn{1}{c}{$\begin{array}{c}\text { Diesel } \\
\text { (No. 2 Oil) }\end{array}$} \\
\hline \%Carbon $(C)$ & 87.49 & 85.84 \\
\%Hydrogen $(H)$ & 9.92 & 12.46 \\
Gross heating value (HHV), kJ/kg & $42,657.34$ & $45,482.52$ \\
Net heating value (LHV), kJ/kg & $40,515.15$ & $42,790.21$ \\
$\mathrm{CO}_{2} \max$ & 16.50 & 15.60 \\
$\%$ Sulfur $(S)$ & 1.40 & 1.60 \\
$\% \mathrm{O}_{2}$ & 1.190 & 0.100 \\
\hline
\end{tabular}

Source: Ohijeagbon et. al [20], TSI Incorporated [29]

Table 5: Specific chemical exergy of material streams in the boiler [19, 30]

\begin{tabular}{ll}
\hline Substance & $\begin{array}{l}\text { Chemical exergy } \\
(\mathrm{kJ} / \mathrm{kg})\end{array}$ \\
\hline Air & 58.79 \\
Steam & 526.33 \\
Water & 49.12 \\
LPFO (Before combustion) $=$ & $42,657.34$ \\
HHV & LPFO \\
$\begin{array}{l}\text { LPFO (During combustion) } \\
\text { Diesel (Before combustion) }=\end{array}$ & $44,566.66$ \\
HHV diesel & $45,482.52$ \\
$\begin{array}{l}\text { Diesel (During combustion) } \\
\text { Exhaust flue gases (LPFO } \\
\text { operated) }\end{array}$ & $44,569.69$ \\
$\begin{array}{l}\text { Exhaust flue gases (Diesel } \\
\text { operated) }\end{array}$ & 147.97 \\
\hline
\end{tabular}

The energy and exergy values and efficiencies of the flow processes in the LPFO and diesel operated boiler which include the physical and chemical exergies were evaluated using equations (1) to (12), the exergetic formulae summarised in Table 6 and the thermodynamic properties of materials streams data presented in Table 7 which was computed according to the method used by Ohijeagbon et. al [19] to determine mass flow rate, temperature, enthalpy and entropy of material streams in a steam boiler at specified node points shown in the material streams flow diagram of Figure 1. The exergetic formulae summarised in Table 6 were determined through energy and exergy balance amalysis in the combustion and heat exchanging units of a boiler system [19-20]. The exergetic values and efficiencies which includes energy input, energy efficiency, exergy destruction and efficiency of the combustion unit; heat loss, energy efficiency, exergy destruction and efficiency of the heat exchanging unit; energy efficiency, overall exergy destruction and efficiency of the entire boiler accordingly. Consequently, a parametric analysis of reference state ambient conditions, entropy effects, and mass flow rates of fuel, feed water and steam temperatures and evaporation ratio on exergetic performance of boilers was carried out, and various exergetic empirical relations was also determined.

Table 6: Summary of exergetic values and efficiencies formulae of steam boilers [19-20]

Energy input $(\mathrm{kJ} / \mathrm{s})$

Adiabatic energy efficiency (\%)

Exergy destruction $(\mathrm{kJ} / \mathrm{s})$

Exergy efficiency (\%)

$$
\dot{E}_{\text {in }}=\dot{m}_{f} h_{f}+\dot{m}_{a} h_{a}
$$$$
\eta_{C}=\frac{\dot{m}_{p} h_{p}}{\dot{m}_{f} \times H H V}
$$$$
\dot{I}_{C}=\dot{m}_{a}\left[\left(h_{a}-T_{0} s_{a}\right)+\varepsilon_{a_{1}}^{c h}\right]-\dot{m}_{p}\left(h_{p}-T_{0} s_{p}\right)
$$$$
+\dot{m}_{f}\left[\left(h_{f}-T_{0} s_{f}\right)+\varepsilon_{f_{2}}^{c h}-\varepsilon_{f_{3}}^{c h}\right]
$$$$
\psi_{C}=\frac{\dot{m}_{p}\left(h_{p}-T_{0} s_{p}\right)}{\dot{m}_{f}\left[\left(h_{f}-T_{0} s_{f}\right)+\varepsilon_{f_{2}}^{c h}-\varepsilon_{f_{3}}^{c h}\right]}
$$

Heat loss $(\mathrm{kJ} / \mathrm{s})$

Energy efficiency (\%)

$$
\text { Heat exchanging unit }
$$$$
\dot{Q}_{H(\text { loss })}=\dot{m}_{p}\left(h_{p}-h_{g}\right)-\dot{m}_{w}\left(h_{s}-h_{w}\right)
$$$$
\eta_{H}=\frac{\dot{m}_{w}\left(h_{s}-h_{w}\right)}{\dot{m}_{p}\left(h_{p}-h_{g}\right)}
$$ 
Exergy destruction (kJ/s)

Exergy efficiency (\%)

$$
\dot{I}_{H}=\dot{m}_{p}\left(h_{p}-T_{0} s_{p}\right)+\dot{m}_{w}\left[\left(h_{w}-T_{0} s_{w}\right)+\varepsilon_{w_{4}}^{c h}\right]
$$$$
-\dot{m}_{s}\left[\left(h_{s}-T_{0} s_{s}\right)+\varepsilon_{s_{5}}^{c h}\right]-\dot{m}_{g}\left[\left(h_{g}-T_{0} s_{g}\right)+\varepsilon_{g_{6}}^{c h}\right]
$$$$
\psi_{H}=\frac{\dot{m}_{s}\left[\left(h_{s}-T_{0} s_{s}\right)+\varepsilon_{s_{5}}^{c h}\right]-\dot{m}_{w}\left[\left(h_{w}-T_{0} s_{w}\right)+\varepsilon_{w_{4}}^{c h}\right]}{\left.\dot{m}_{p}\left(h_{p}-T_{0} s_{p}\right)-\dot{m}_{g}\left[\left(h_{g}-T_{0} s_{g}\right)+\varepsilon_{g_{6}}^{c h}\right)\right]}
$$

\section{Entire boiler}

Energy efficiency (\%)

$$
\eta_{B}=\frac{\dot{m}_{S}\left(h_{s}-h_{w}\right)}{\dot{m}_{f} h_{f}}
$$

Overall exergy destruction $(\mathrm{kJ} / \mathrm{s})$

$$
\dot{I}_{B}=\dot{I}_{C}+\dot{I}_{H}
$$

\begin{tabular}{|c|c|c|c|c|c|c|c|c|c|}
\hline \multirow[b]{2}{*}{ Point } & \multirow[b]{2}{*}{ Stream } & \multicolumn{2}{|c|}{ Mass flow rate $(\mathrm{kg} / \mathrm{s})$} & \multicolumn{2}{|c|}{ Temperature $\left({ }^{\circ} \mathrm{C}\right)$} & \multicolumn{2}{|c|}{ Enthalpy $(\mathrm{kJ} / \mathrm{kg})$} & \multicolumn{2}{|c|}{ Entropy $(\mathrm{kJ} / \mathrm{kgK})$} \\
\hline & & $\begin{array}{c}\text { LPFO } \\
\text { operated }\end{array}$ & $\begin{array}{c}\text { Diesel } \\
\text { operated }\end{array}$ & $\begin{array}{c}\text { LPFO } \\
\text { operated }\end{array}$ & $\begin{array}{c}\text { Diesel } \\
\text { operated }\end{array}$ & $\begin{array}{c}\text { LPFO } \\
\text { operated }\end{array}$ & $\begin{array}{c}\text { Diesel } \\
\text { operated }\end{array}$ & $\begin{array}{c}\text { LPFO } \\
\text { operated }\end{array}$ & $\begin{array}{c}\text { Diesel } \\
\text { operated }\end{array}$ \\
\hline 1 & Air, $\dot{m}_{a}$ & 2.90 & 3.06 & 77.00 & 77.00 & 350.49 & 350.49 & 1.8571 & 1.8571 \\
\hline 2 & Fuel, $\dot{m}_{f}$ & 0.18 & 0.18 & 1345.69 & 1289.13 & 40515.15 & 42790.21 & 1.6664 & 1.7337 \\
\hline 3 & $\begin{array}{l}\text { Hot products, } \\
\qquad \dot{m}_{p}\end{array}$ & 3.08 & 3.24 & 342.03 & 327.66 & 2697.38 & 2708.25 & 4.3857 & 4.5088 \\
\hline 4 & $\begin{array}{l}\text { Feed water, } \\
\dot{m}_{w}\end{array}$ & 2.16 & 2.16 & 100.00 & 100.00 & 419.10 & 419.10 & 1.3070 & 1.3070 \\
\hline 5 & Steam, $\dot{m}_{s}$ & 2.16 & 2.16 & 170.40 & 170.40 & 2768.30 & 2768.30 & 6.6616 & 6.6616 \\
\hline 6 & $\begin{array}{l}\text { Exhaust flue } \\
\text { gas, } \dot{m}_{g}\end{array}$ & 3.08 & 3.24 & 148.84 & 146.32 & 223.46 & 218.85 & 2.6882 & 2.7475 \\
\hline
\end{tabular}

Overall exergy efficiency (\%)

Table 7: Thermodynamic analysis of material streams for the diesel and LPFO operated boiler

\section{RESULTS AND DISCUSSION}

\subsection{Thermodynamics of material streams flow}

The same values of combustion air temperature 77.00 ${ }^{0} \mathrm{C}$, steam pressure $800 \mathrm{kN} / \mathrm{m}^{2}$, mass flow rate of fuel $0.18 \mathrm{~kg} / \mathrm{s}$, evaporation ratio 12 , and excess air $20 \%$ respectively used in the analysis of the boiler operation resulted in higher fuel combustion temperature of $1345.69{ }^{\circ} \mathrm{C}$ in the LPFO operated boiler compared with $1289.13{ }^{\circ} \mathrm{C}$ in the diesel operated boiler as presented in Table 7. This was attributed to lower values of the specific heat capacity and air fuel ratio of LPFO as presented in Table 2 and used for computing the combustion fuel temperatures in the energy balance equation of the combustion unit. Consequently, higher combustion fuel temperature resulted in higher temperatures of products of hot flue and exhaust gases as indicated in Table 7.

\subsection{Exergetic modelling}

Previously derived thermodynamic formulations to determine exergetic values and efficiencies in a steam boiler operation given in Table 6 were used to develop empirical models for estimations and applications of oil fired steam boilers. Averaged values of thermodynamic variables, standard reference state temperature, specific chemical exergy of material streams and heating values given in Tables 4, 5 and 7, the exergetic expressions contained in Table 6 and expression relating $A A F$ to $A F R_{s t}$ [19] were used to obtain the exergetic models given in equations (13) to (28).

$$
\begin{aligned}
& E_{\text {in }}=m_{f}\left[350.49(1+E A) A F R_{s t}+41652.68\right] \\
& \eta_{C(\text { LPFO })}=5.8433\left[(1+E A) A F R_{s t}+1\right] \\
& \eta_{C(\text { Diesel })}=5.57\left[(1+E A) A F R_{s t}+1\right] \\
& \dot{I}_{C}=m_{f}\left[39270.29-1521.66(1+E A) A F R_{s t}\right] \\
& \psi_{C}=3.39\left[(1+E A) A F R_{s t}+1\right] \\
& \dot{Q}_{H(\text { loss })}=m_{f}\left[2481.66\left\{(1+E A) A F R_{s t}+1\right\}-2349.20 E_{r}\right]
\end{aligned}
$$




$$
\begin{aligned}
\eta_{H} & =\frac{94.66 E_{r}}{\left[(1+E A) A F R_{s t}+1\right]} \\
\dot{I}_{H} & =m_{f}\left[1817.92\left\{(1+E A) A F R_{s t}+1\right\}-1230.74 E_{r}\right]
\end{aligned}
$$

$\psi_{H}=\frac{67.7 E_{r}}{\left[(1+E A) A F R_{s t}+1\right]}$

$\eta_{B}=5.64 E_{r}$

$\dot{I}_{B}=m_{f}\left[296.26(1+E A) A F R_{s t}-1230.74 E_{r}+41088.21\right]$

$\psi_{B}=3.03 E_{r}$

From equations (14), (15) and (17), the relation between the energy and exergy efficiencies of an adiabatic combustion unit of a steam boiler can be expressed respectively for LPFO and diesel operated boilers as

$$
\begin{aligned}
& \eta_{C(L P F O)}=1.724 \psi_{C} \\
& \eta_{C(\text { Diesel })}=1.643 \psi_{C}
\end{aligned}
$$

From (19) and (21), the energy and exergy efficiencies relation of a heat exchanging unit of a steam boiler may be expressed as

$$
\eta_{H}=1.4 \psi_{H}
$$

From (22) and (24), the energy and exergy efficiencies relation of an entire steam boiler may be expressed as:

$$
\eta_{B}=1.8614 \psi_{B}
$$

The models make it possible to estimate vital exergetic information on the performance evaluation of oil-fired steam boilers with minimum input operational parameters, such as mass flow rate of fuel, air-fuel ratio and evaporation ratio. The models developed assumed linearity, as the respective coefficient of correlation and standard error of estimate obtained was approximately 1.00 and 0.00 respectively. The ratio of energy to exergy efficiencies of steam boiler was obtained as 1.8614. Previous study by Mehdi and Amir [31], obtained the energy to exergy efficiencies relation of boiler as 1.962, suggesting relatively higher energy or lower exergy efficiencies compared to that represented by the developed models in this study; they obtained the energy and exergy efficiencies of boiler to be $89.21 \%$ and $45.48 \%$, respectively. The higher energy obtained in their study could be attributed to higher evaporation ratio of 15.26. Applying the evaporation ratio used by Mehdi and Amir [31] into the exergetic efficiency models developed and given by equations (22) and (24), results in energy and exergy efficiency of $88.21 \%$ and $46.24 \%$ respectively which compare favourably with those obtained by Mehdi and Amir [31].

\subsection{Exergetic losses with changes in evaporation ratio and mass flow rate of fuel}

Thermodynamic variables are critical to the exergetic performance and energy savings of steam boilers; hence, it is highly imperative to understand the mode of performance outputs with operational variables, such as, evaporation ratio and mass flow rates of fuel. Figure 2 shows that exergetic losses increased in boiler with changes in mass flow rate of fuel at constant evaporation ratio, while Figure 3 shows reducing values in exergetic losses with changes in evaporation ratio at constant mass flow rate of fuel. This clearly indicates that reduction in exergetic losses and consequently energy savings can be achieved in steam boilers by maintaining the input fuel value and increasing the evaporation ratio of steam boiler operation. Table 7 shows that the same steam pressure of $800 \mathrm{kN} / \mathrm{m}^{2}$ resulted in the same saturated steam temperature of $170.00{ }^{\circ} \mathrm{C}$. This implies that higher energy loss and exergy destruction are experienced in the heat exchanging unit of the diesel operated boiler as against that of the LPFO operated boiler as shown in Figures 2 and 3.

The overall exergy destruction of LPFO and diesel operated boilers were nearly the same irrespective of changes in evaporation ratio and mass flow rate of fuel. This is attributed to the same values of evaporation ratio, excess air and mass flow rate of fuel assumed for both boiler operations. The average overall boiler exergy destruction in the LPFO and diesel operated boiler operations increased from 3121.76 to $9365.27 \mathrm{~kJ} / \mathrm{s}$ as the mass flow rate increases from 0.1 to $0.3 \mathrm{~kg} / \mathrm{s}$, while the average overall boiler exergy destruction decreased from 6062.23 to $5176.10 \mathrm{~kJ} / \mathrm{s}(14.62 \%)$ as the evaporation ratio increases from 10 to 14 respectively 


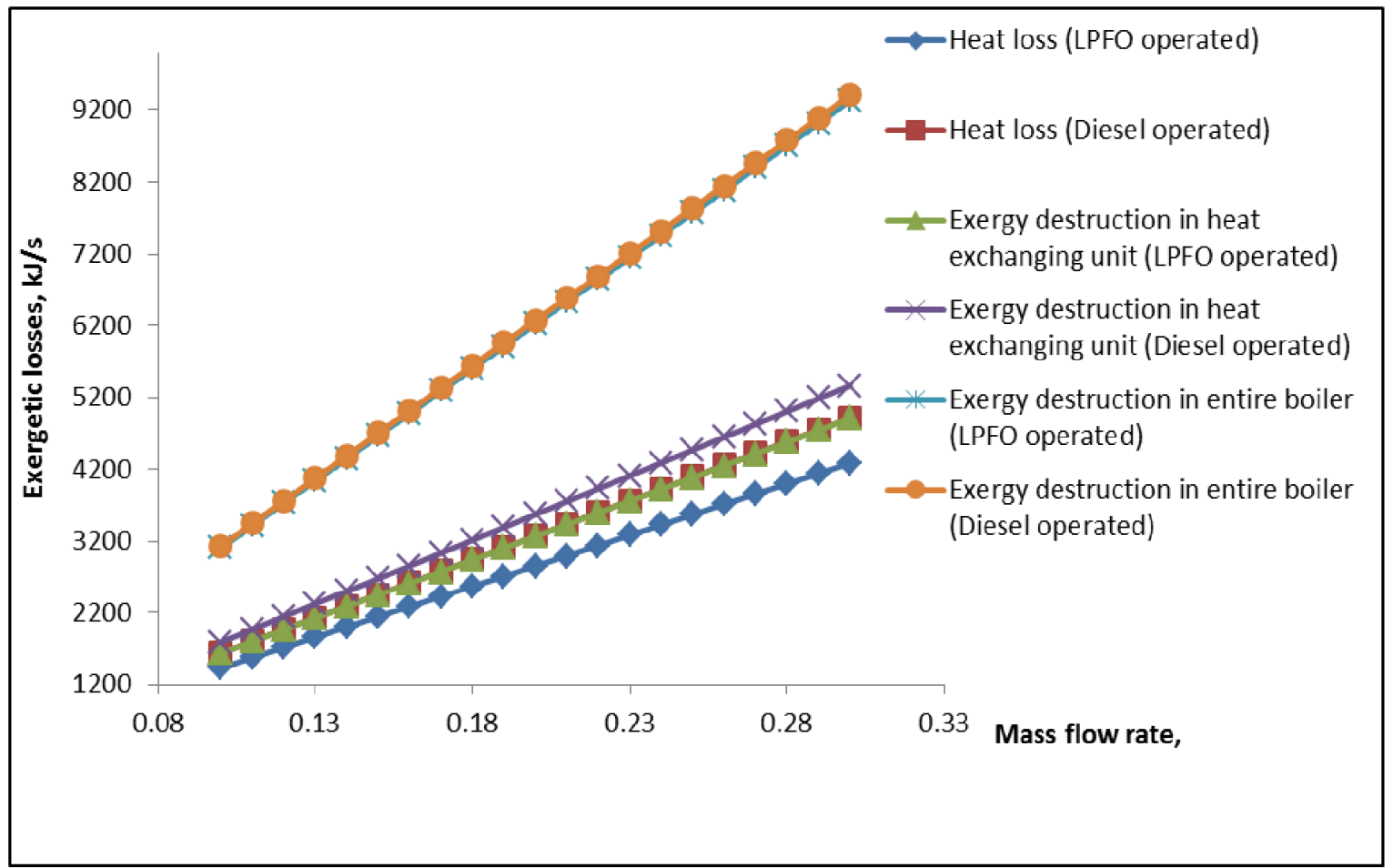

Figure 2: Exergetic losses in boiler with changes in mass flow rate of fuel at constant evaporation ratio

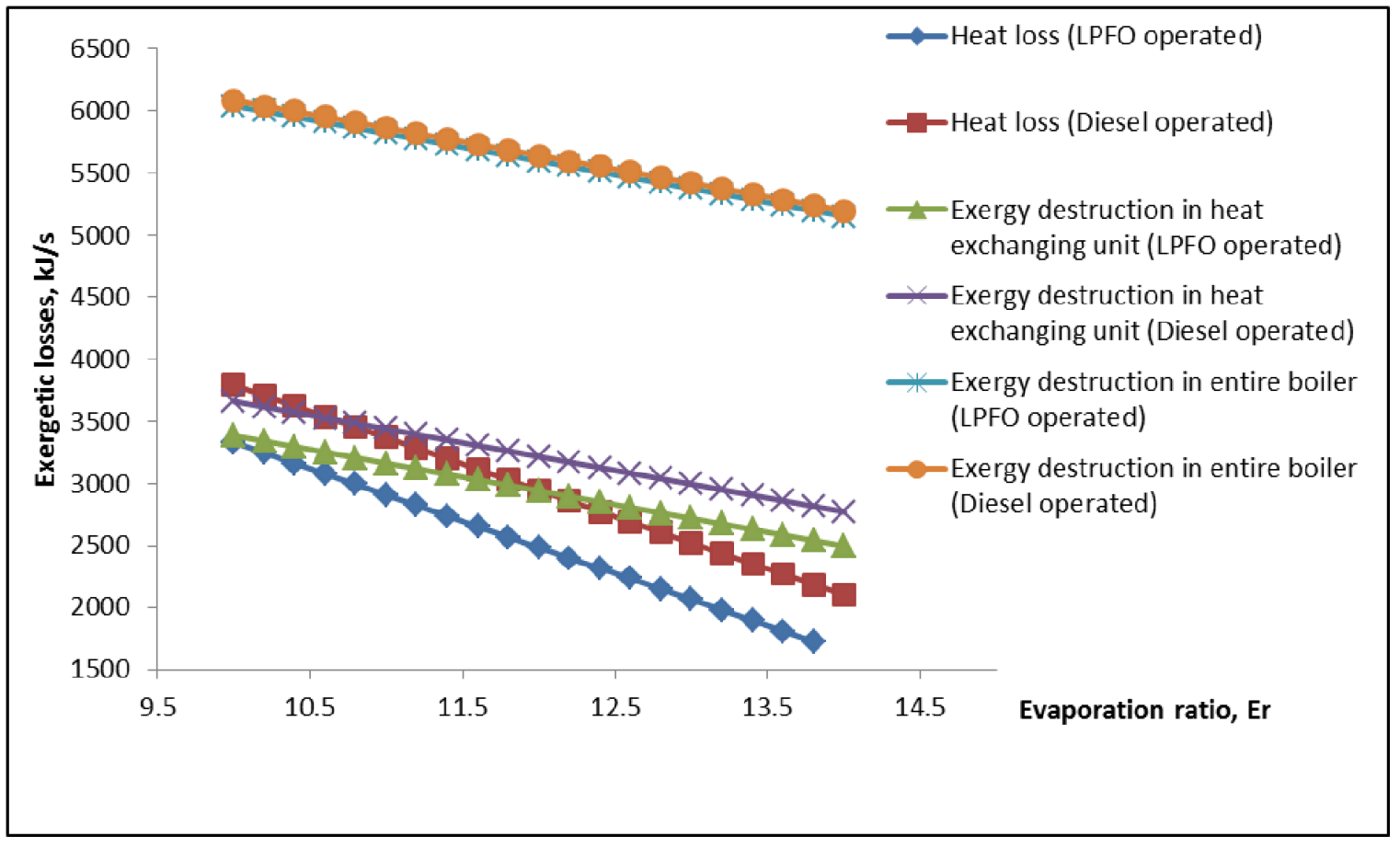

Figure 3: Exergetic losses in boiler with changes in evaporation ratio at constant mass flow rate of fuel

3.4 Effects of reference state temperature, entropy, feed water and steam temperatures

Figure 4 clearly shows reducing values in exergy efficiency with corresponding increases in reference state temperature, consequently, increases in exergy destruction in all units in a boiler. This is an indication that it is more advantageous to keep ambient temperature of a boiler system as low as possible.
The combustion unit and entire boiler exergy efficiencies experienced slight decreases in exergy destruction and slight increases in exergy efficiencies as fuel entropy was increasing as shown in Figure 5, while Figure 8 shows that the heat exchanging unit and entire boiler experienced slight increases in exergy destruction and slight decreases in exergy efficiencies as feed water temperature and entropy 
was increasing. The average factor of exergy efficiency to entropy changes due to fuel entropy and feed water entropy was determined as 0.015 and 0.049 accounting as the lowest. The average factor of exergy efficiency to entropy changes due to exhaust flue gas entropy, combustion product entropy in heat exchanging and combustion units and superheated steam entropy were determined as $0.51,0.76,1.29$ and 3.85 respectively from Figures 6, 7 and 9. This indicates that the largest amount of entropy changes in a boiler system is due to superheated steam entropy. As shown in Figure 9, increasing superheated steam temperature and entropy would result in decreases in exergy destruction and possible energy savings since superheated steam can be achieved by recycling of waste heat in boilers.

Figure 6 shows that combustion product entropy would result in increase in exergy destruction in the combustion unit while it leads to decreases in exergy destruction in the heat exchanging unit. Increases in flue gas entropy results in increases in exergy destruction in the heat exchanging unit as shown by Figure 7. The Figures 5 to 9 show that the key area to control irreversibility resulting from entropy effects is that due to combustion product entropy which leads to increased exergy destruction in the combustion unit.

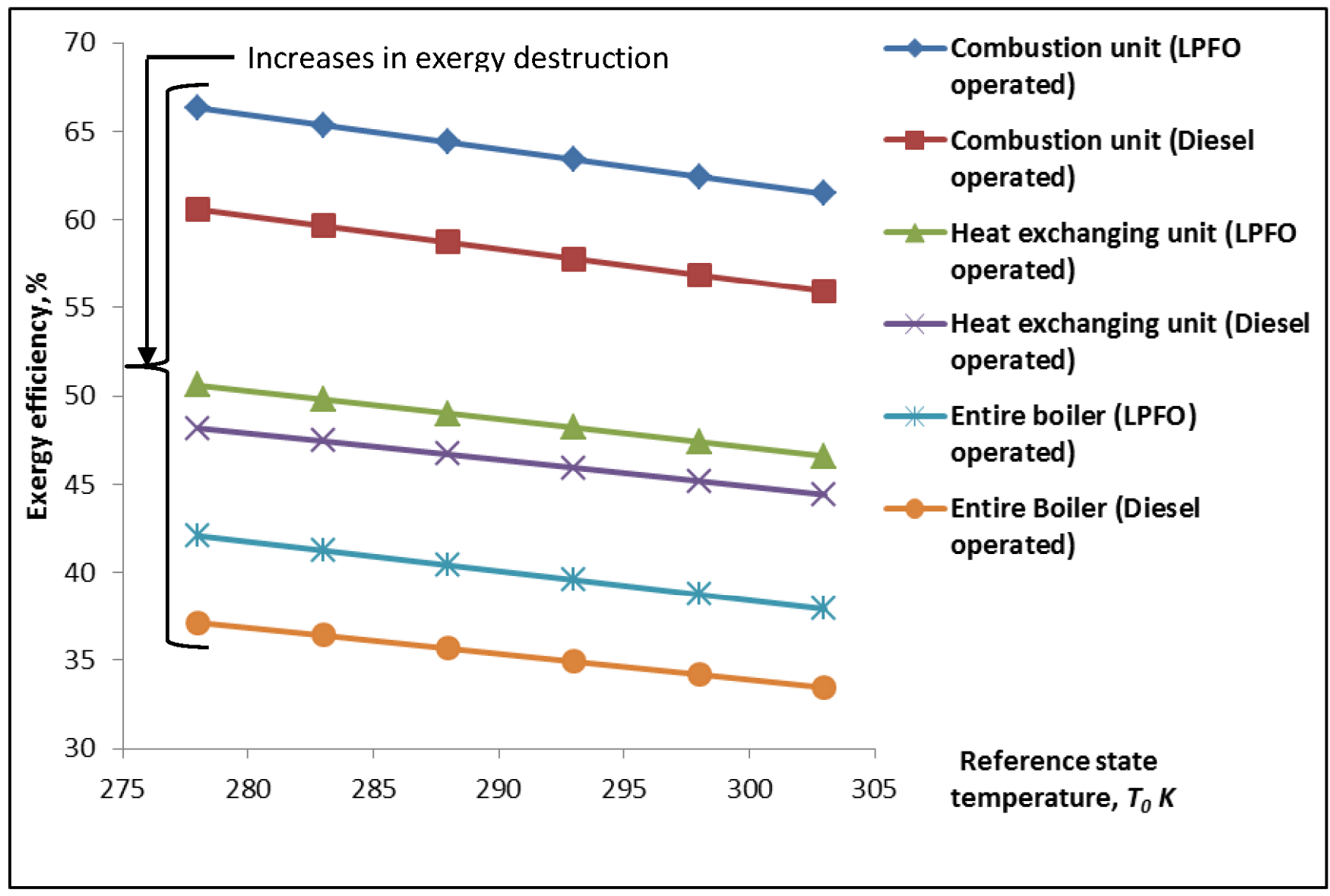

Figure 4: Exergy efficiency in boiler at different reference state 


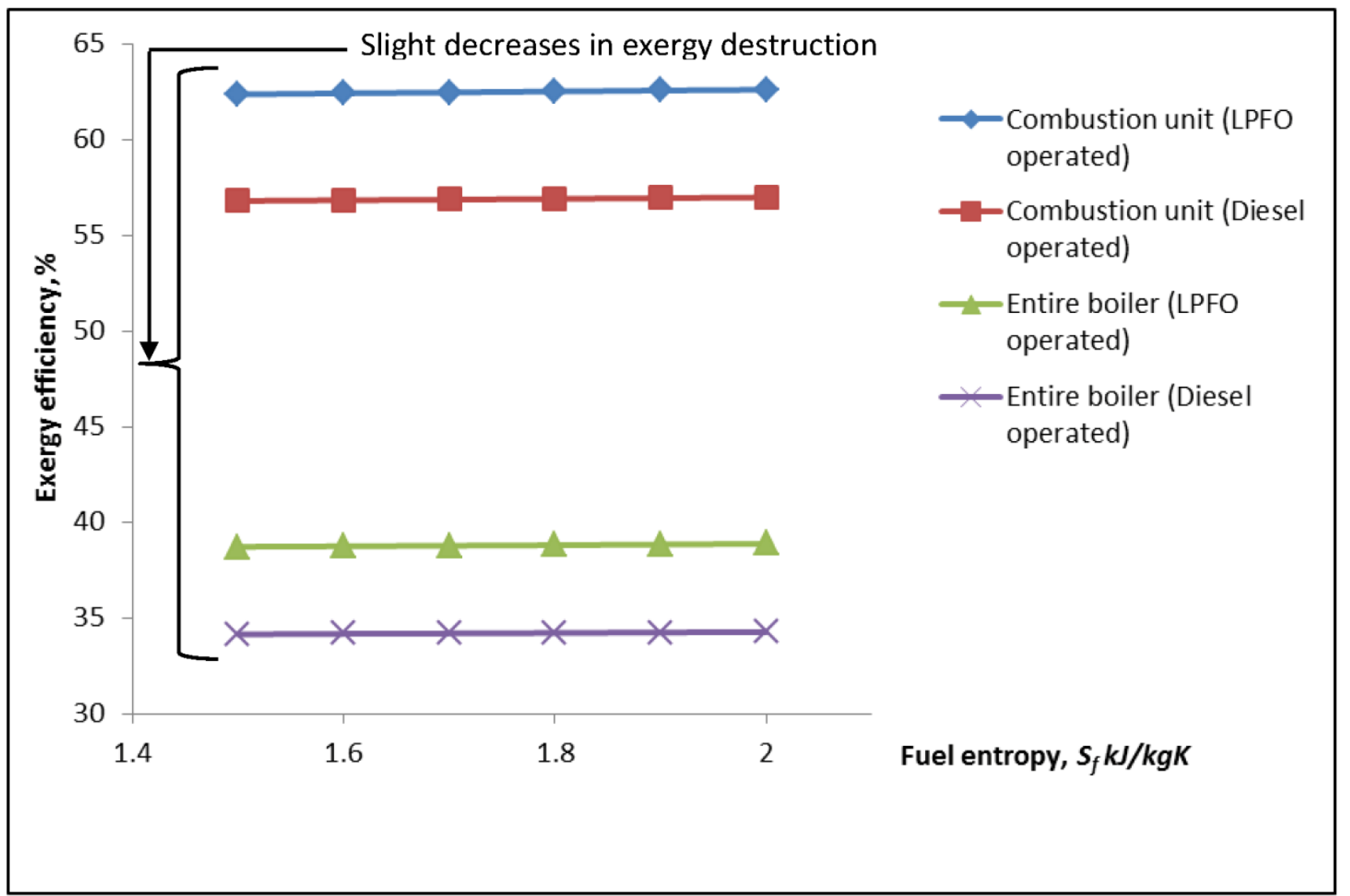

Figure 5: Exergy efficiency in boiler with respect to combustion fuel entropy

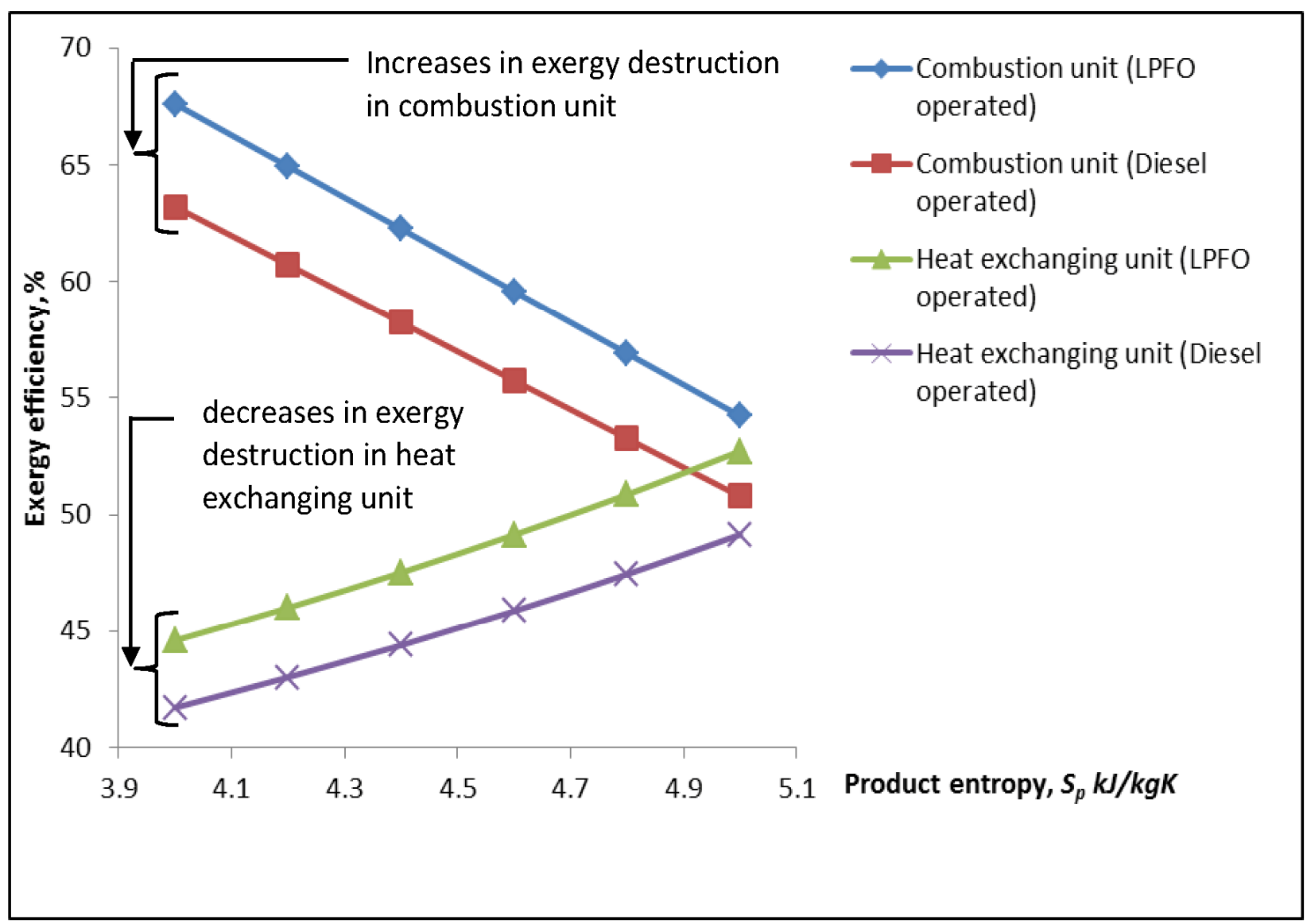

Figure 6: Exergy efficiency in boiler with respect to combustion product entropy 


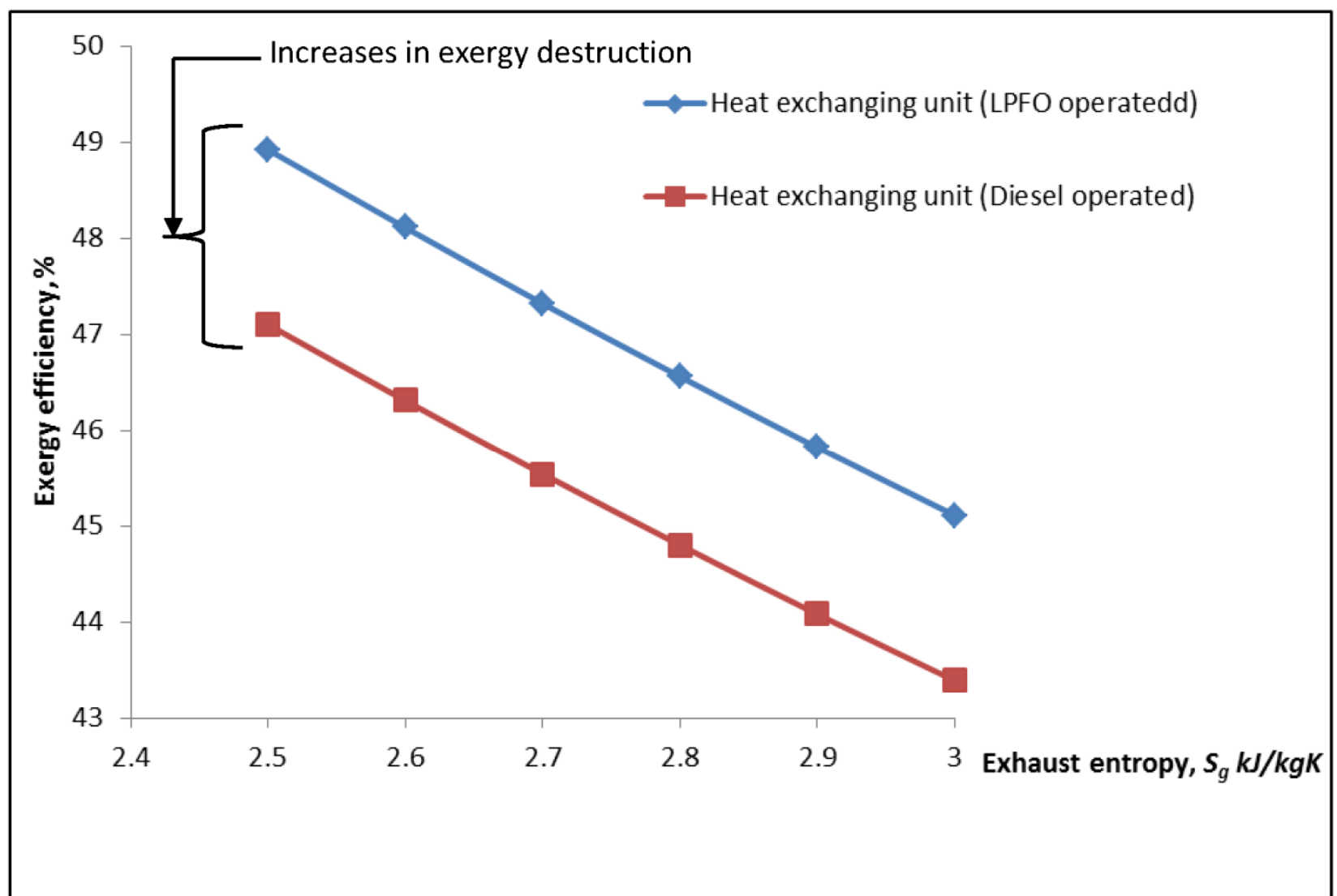

Figure 7: Exergy efficiency in boiler with respect to exhaust flue gas entropy

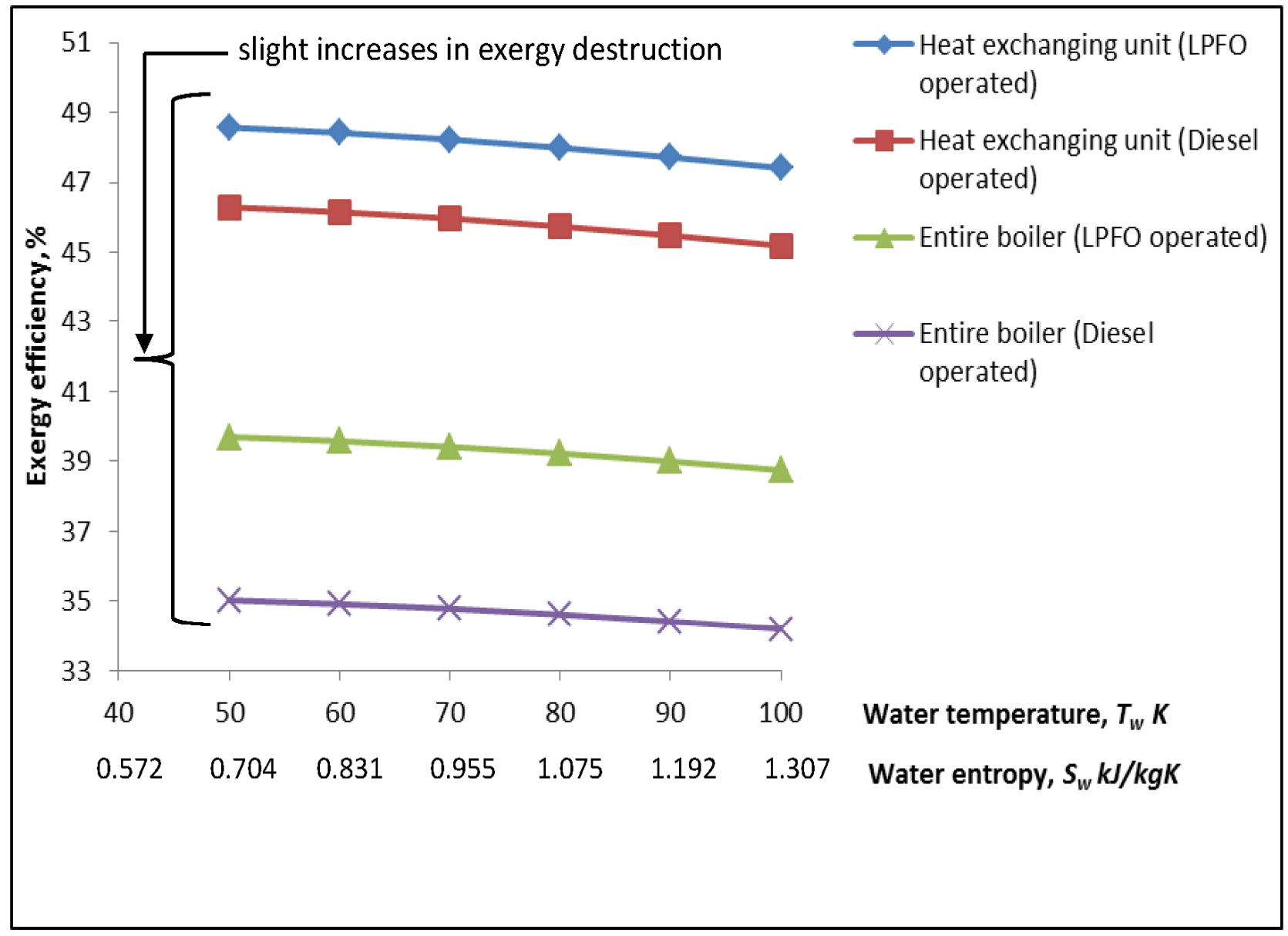

Figure 8: Exergy efficiency in boiler with respect to feed water temperature/entropy 


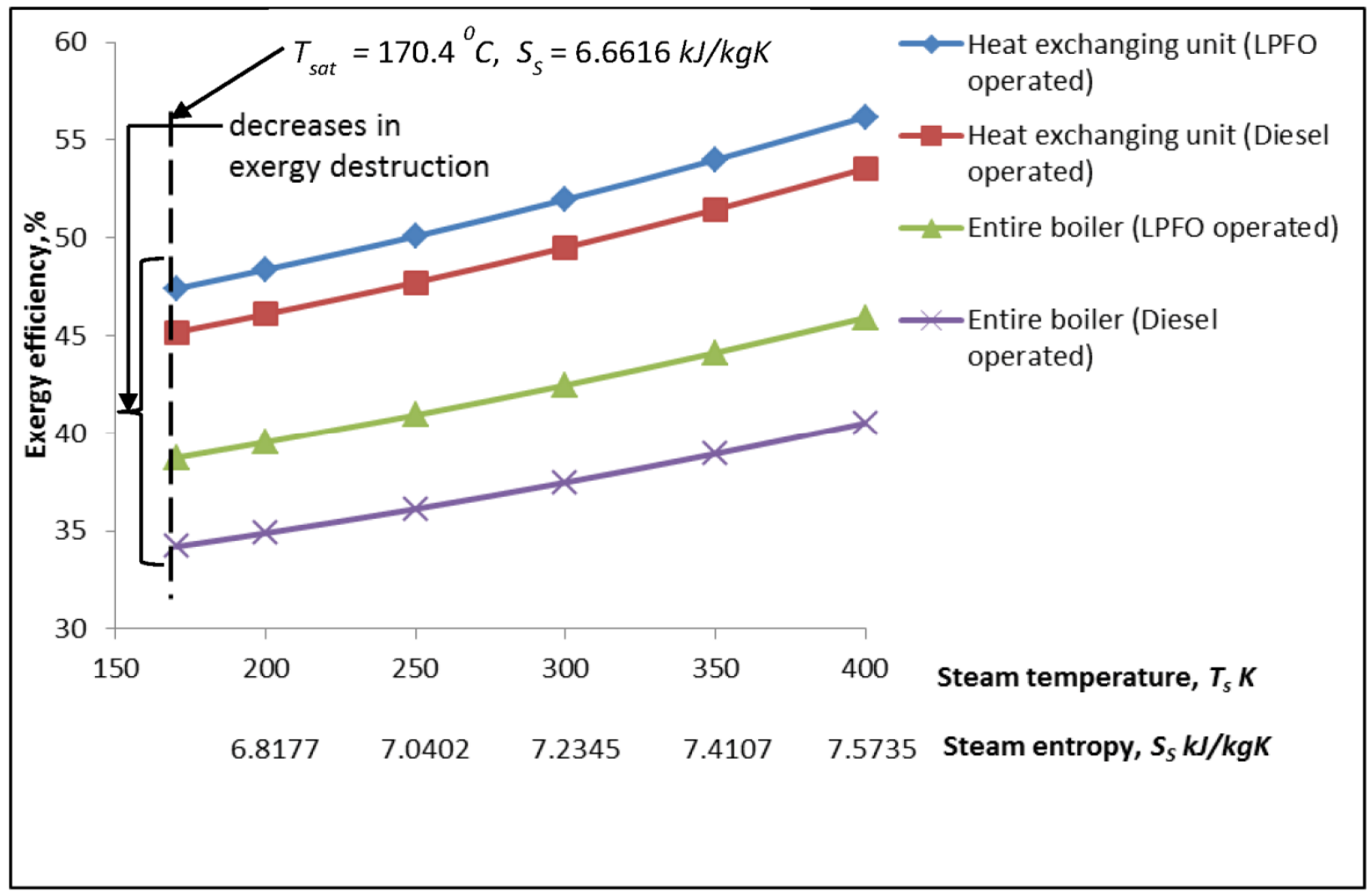

Figure 9: Exergy efficiency in boiler with respect to super heated steam temperature/entropy

\section{CONCLUSION}

Exergetic models to estimate exergetic quantities and efficiencies for performance evaluation of oil-fired steam boilers with minimum input operational parameters as mass flow rate of fuel, air-fuel ratio and evaporation ratio have been developed. The relation between the energy and exergy efficiencies of an adiabatic combustion unit for LPFO and diesel operated boilers, heat exchanging unit and of an entire steam boiler have been determined as

$\eta_{C(L P F O)}=1.724 \psi_{C}, \quad \eta_{C(\text { Diesel })}=1.643 \psi_{C}$, $\eta_{H}=1.4 \psi_{H}$ and $\eta_{B}=1.8614 \psi_{B}$ respectively. Reduction in exergetic losses and subsequently gain in energy savings can be achieved in steam boilers by maintaining the input fuel value and increasing the evaporation ratio of steam boiler operation. The average overall boiler exergy destruction decreased from 6062.23 to $5176.10 \mathrm{~kJ} / \mathrm{s}$, that is, $14.62 \%$ as the evaporation ratio increased from 10 to 14 . Increase in superheated steam temperature results in decreases in exergy destruction and possible energy savings as superheated steam can be achieved by recycling of waste heat in boilers. The major area to control irreversibility resulting from entropy effects is the combustion product entropy which leads to increased exergy destruction in the combustion unit. Increasing feed water temperature resulted in slight increases in exergy destruction of heat exchanging unit and entire boiler.

\section{REFERENCES}

[1] Ayhan, B. and Demirtas, C. "Investigation of Turbulators for Fire Tube Boilers Using Exergy Analysis", Turk J Engin Environ Sci. TUBITAK, 25, pp.249-258, 2001.

[2] Dincer, I. and Cengel, Y. A. "Energy, Entropy and Exergy Concepts and Their Roles in Thermal Engineering", Entropy, 3, pp.116-149, 2001.

[3] Hepbasli, A. "A Study on Estimating the Energetic and Exergetic Prices of Various Residential Energy Sources", Energy and Buildings, 40, pp.308-315, 2008.

[4] Utlua, Z. and Hepbasli, A. "A review on Analyzing and Evaluating the Energy Utilization Efficiency of Countries", Renewable and Sustainable Energy Reviews, 11, pp.1-29, 2007.

[5] Rajput, R. K. "Thermal Engineering", Laxmi Publications (P) Ltd., New Delhi, 2006.

[6] Aljundi, I. H. "Energy and Exergy Analysis of a Steam Power Plant in Jordan", Applied Thermal Engineering, 29, pp.324-328, 2009.

[7] Rosen, M. A. "Energy-and Exergy-based Comparison of Coal-Fired and Nuclear Steam Power Plants", 
Exergy, an International Journal, 1(3), pp.180-192, 2001.

[8] Taniguchi, H., Mouri, K., Nakahara, T. and Arai, N. "Exergy Analysis on Combustion and Energy Conversion Processes", Energy, 30, pp.111-117, 2005.

[9] Struchtrup, H. and Rosen, M. A. "How Much Work is Lost in an Irreversible Turbine", Exergy, an International Journal, 2, pp.152-158, 2002.

[10] Ostrovski, O. and Zhang, G. "Energy and Exergy Analyses of Direct Ironsmelting Processes". Energy, 30, pp.2772-2783, 2005.

[11] Suresh, M.V.J.J., Reddy, K. S. and Kolar, A. K. “Energy and Exergy Analysis of Thermal Power Plants Based on Advanced Steam Parameters", Advances in Energy Research (AER - 2006), pp.15-21, 2006.

[12] Goncalves, L. P. and Arrieta, F. R. P. "An Exergy Cost Analysis of a Cogeneration Plant", Engenharia Termica (Thermal Engineering, 9 (1 and 2), pp.2834,2010 .

[13] Ataei, C. and Yoo, C. "Combined Pinch and Exergy Analysis for Energy Efficiency Optimization in a Steam Power Plant", International Journal of the Physical Sciences, 5(7), pp.110-1123, 2010.

[14] Srinivas, T., Gupta, A.V.S.S.K.S. and Reddy, B. V. "Generalized Thermodynamic Analysis of Steam Power Cycles with ' $n$ ' Number of Feedwater Heaters", Int. J. of Thermodynamics, 10 (4), pp.177185, 2007.

[15] Gutierrez, F. and Mendez, F. "Entropy Generation Minimization of a Thermoelectric Cooler", The Open Thermodynamics Journal, 2, pp.71-81, 2008.

[16] Orosun, R. O. and Adamu, S. S. "Neural Network Based Model of an Industrial Oil-fired Boiler System", Nigerian Journal of Technology (NIJOTECH), 33 (3), pp.293-303, 2014.

[17] Igboanugo, A. C., Asalor, J. O. and Egbiremon, V. I. "Assessment of Some Performance Characteristics of Refuse Boiler Before and After Overhaul Using Failure Mode Effect and Fault Tree Analyses", Nigerian Journal of Technology (NIJOTECH), 32 (2), pp.333-349, 2013.

[18] Saidur, R., Ahamed, J. U. and Masjuki, H. H. "Energy, Exergy and Economic Analysis of Industrial Boilers", Energy Policy, 38, pp.2188-2197, 2010.

[19] Ohijeagbon, I. O., Waheed, M. A. and Jekayinfa, S. O. "Methodology for the Physical and Chemical
Exergetic Analysis of Steam Boilers", Energy, 53, pp.153-164, 2013.

[20] Ohijeagbon, I. O., Jekayinfa, S. O. and Waheed, M. A. "Cumulative Exergetic Assessment of LPFO Utilised Steam Boilers", Int. J. Exergy, 11(1), pp.19-135, 2012.

[21] Bureau of Energy Efficiency "Energy Performance Assessment of Boilers" www.em-ea.org/Guide Books/book-4/4.1Boiler.pdf, Accessed on December 9, 2010.

[22] Cornelissen, R. L. "Thermodynamics and Sustainable Development-The Use of ExergyAnalysis and the Reduction of Irreversibility" Enschede, The Netherlands, 2-5, pp.11-14, 1997.

[23] Dincer, I. and Rosen, M. A. "Exergy: Energy, Environment and Sustainable Development", Elsevier, London, 2007.

[24] Talens, L., Villalba, G. and Gabarrell, X. "Exergy Analysis Applied to Biodiesel Production", Elsevier (Resources, Conservation and Recycling), 51, pp397-407, 2007.

[25] "Chemical Exergy" www.oocities.org/ pldhar/Lecture 7 5.ppt, Accessed on July 4, 2011.

[26] Ertesvag, I. S. "Sensitivity of the Chemical Exergy for Atmospheric Gases and Gaseous Fuels to Variations in Ambient Conditions", Energy Conservation and Management, 48, pp.19831995, 2007.

[27] Roger, G. F. C. and Mayhew, Y. R. "Engineering Thermodynamics: Work and Heat Transfer", Longman group limited, 4th ed. UK, 1992.

[28] Jorge Luis Hau, M. S. “Toward Environmentally Conscious Process Systems Engineering via Joint Thermodynamic Accounting of Industrial and Ecological Systems", Doctor of philosophy dissertation, USA: Ohio state university, 2005.

[29] TSI Incorporated "Combustion Analysis Basics: An Overview of Measurements, Methods and Calculations Used in Combustion Analysis". www.tsi.com, 2004.

[30] Szargut, J., Valero, A., Stanek, W. and Valero A. "Towards an International Reference Environment of Chemical Exergy", http://www.exergoecology.com /papers/towards int re.pdf, Accessed on May 20, 2011.

[31] Mehdi, B. and Amir, V. "Boiler Parametric Study to Decrease Irreversibility”, Indian Journal of Science and Technology, 5 (4), pp.2534-2539, 2012. 